Article

\title{
Biofilm Produced In Vitro by Piscirickettsia salmonis Generates Differential Cytotoxicity Levels and Expression Patterns of Immune Genes in the Atlantic Salmon Cell Line SHK-1
}

\author{
Natacha Santibañez ${ }^{1,2}$, Matías Vega ${ }^{1}$, Tatiana Pérez ${ }^{1,2}$, Alejandro Yáñez ${ }^{2,3}$, \\ Roxana González-Stegmaier ${ }^{1}$, Jaime Figueroa ${ }^{2,4}$, Ricardo Enríquez ${ }^{1}$, Cristian Oliver ${ }^{1, *}$ (C) \\ and Alex Romero ${ }^{1,2, *}$ \\ 1 Laboratorio de Inmunología y Estrés de Organismos Acuáticos, Instituto de Patología Animal, \\ Facultad de Ciencias Veterinarias, Universidad Austral de Chile, Campus Isla Teja, Valdivia 5090000, Chile; \\ natacha.santi@gmail.com (N.S.); matias.vega.n@gmail.com (M.V.); tatybioq@gmail.com (T.P.); \\ rgstegmaier@gmail.com (R.G.-S.); renrique@uach.cl (R.E.) \\ 2 Interdisciplinary Center for Aquaculture Research (INCAR), Concepción 4070386, Chile; \\ ayanez@uach.cl (A.Y.); jefigueroa@uach.cl (J.F.) \\ 3 Facultad de Ciencias, Universidad Austral de Chile, Valdivia 5090000, Chile \\ 4 Instituto de Bioquímica y Microbiología, Facultad de Ciencias, Universidad Austral de Chile, \\ Valdivia 5090000, Chile \\ * Correspondence: cristianoliver7@gmail.com (C.O.); alexromero@uach.cl (A.R.)
}

Received: 8 August 2020; Accepted: 19 September 2020; Published: 20 October 2020

\begin{abstract}
Piscirickettsia salmonis is the causative agent of Piscirickettsiosis, an infectious disease with a high economic impact on the Chilean salmonid aquaculture industry. This bacterium produces biofilm as a potential resistance and persistence strategy against stressful environmental stimuli. However, the in vitro culture conditions that modulate biofilm formation as well as the effect of sessile bacteria on virulence and immune gene expression in host cells have not been described for P. salmonis. Therefore, this study aimed to analyze the biofilm formation by P. salmonis isolates under several $\mathrm{NaCl}$ and iron concentrations and to evaluate the virulence of planktonic and sessile bacteria, together with the immune gene expression induced by these bacterial conditions in an Atlantic salmon macrophage cell line. Our results showed that $\mathrm{NaCl}$ and $\mathrm{Fe}$ significantly increased biofilm production in the LF-89 type strain and EM-90-like isolates. Additionally, the planktonic EM-90 isolate and sessile LF-89 generated the highest virulence levels, associated with differential expression of $i l-1 \beta, i l-8, n f-\kappa b$, and $i \kappa b-\alpha$ genes in SHK-1 cells. These results suggest that there is no single virulence pattern or gene expression profile induced by the planktonic or sessile condition of P. salmonis, which are dependent on each strain and bacterial condition used.
\end{abstract}

Keywords: Piscirickettsia salmonis; SRS; biofilm; gene expression; bacterial virulence

\section{Introduction}

Chilean fish farming has gone through a tremendous expansion over the last decades including the culture of three main salmonids species such as Atlantic salmon (Salmo salar), Coho salmon (Oncorhynchus kisutch), and rainbow trout (O. mykiss). Unfortunately, increased fish farming has been accompanied by the development of novel infectious-contagious diseases caused mainly by viral, parasitic, and bacterial pathogens. Piscirickettsiosis is the most prevalent bacterial disease for salmonids in Chilean aquaculture [1]. This disease is caused by Piscirickettsia salmonis, a $\gamma$-proteobacteria classified into two different genogroups associated with the LF-89T (ATCC VR-1361) type strain and the Chilean 
isolate EM-90 [2,3]. P. salmonis possess the type IV secretion system $[4,5]$, which secretes effector proteins during in vivo infection [6]. Likewise, P. salmonis secretes outer membrane vesicles (OMVs) [7], which transport several virulence proteins and toxins to the extracellular environment and within the host cell, and are involved in bacterial virulence [8].

Biofilm is a highly complex, well-organized three-dimensional structure and cooperating community of microorganisms, regulated by nutrient availability and several environmental factors such as osmolarity, $\mathrm{pH}$, temperature, oxygen content, and iron [9-12]. Living in biofilms is a natural state of occurring bacteria [13], allowing complex interactions between cells and with the biofilm matrix: this grants emergent properties at the community level that are not apparent at the level of individual free-living cells. Thus, the matrix can also act as a "protective shield" as a survival and persistence strategy under stressful conditions [14]. This makes mechanical removal of bacteria organized in biofilms very difficult, demonstrating greater resistance to disinfectants and antimicrobials [15]. Isiaku et al. [16] and Thuptimdang et al. [17] reported that biofilms play an important role in bacterial pathogenicity, especially in chronic infections where the physical and spatial arrangement of these structures impede the access of bactericidal drugs; restricting their effects to the surface, making them extraordinarily resistant to phagocytosis, and increasing the difficulty of eradicating the biofilm from their hosts [18-20].

Marshall et al. [21] described that P. salmonis cultured in nutritional restricted media generated exopolysaccharides aggregates, which are similar to typical biofilm structures. This suggests that this pathogen may produce biofilms as a way to survive and persist in marine surroundings or simply as an independent defense feature against hostile environmental conditions. Similarly, several fish pathogens such as Streptococcus phocae [22], Vibrio ordalii [23], Flavobacterium columnare [24], and F. psychrophilum [25] can attach to different materials commonly found in fish farms and form biofilms, causing recurrent exposure to pathogens and, consequently, asymptomatic carriers [26-28]. Thus, bacterial adhesion and growth through biofilm production could be considered as a major virulence factor involved in the pathogenicity of P. salmonis [29]. P. salmonis express the chemotaxis operon cheYZA [30] and several genes involved in biofilm biosynthesis [3]. Interestingly, Levipán et al. [29] reported that two isolates of P. salmonis formed biofilms in seawater and AUSTRAL-SRS broth. This study also described the cytotoxicity generated by the biofilm of these isolates in SHK-1 cells. However, no published studies have evaluated the host immune response induced by $P$. salmonis biofilms. Thus, this study aimed to determine and analyze the biofilm formation of different $P$. salmonis isolates under several culture conditions and to evaluate the virulence of planktonic and sessile bacteria and the immune gene expression induced by these bacterial conditions in Salmo salar head kidney (SHK-1) cells.

\section{Materials and Methods}

\subsection{Bacterial Strains and Culture Conditions}

P. salmonis LF-89 ${ }^{\mathrm{T}}$ (ATCC VR-1361) type strain and the Chilean isolates LF-89-like 1, EM-90-like 1, and EM-90-like 2 were routinely grown as a bacterial lawn on BBL ${ }^{\mathrm{TM}}$ Trypticase Soy Agar (Becton, Dickinson and Company, Sparks, MD, USA) plates supplemented with $\mathrm{NaCl} 15 \mathrm{~g} / \mathrm{L}$, fetal bovine serum (FBS) $5 \%$, L-cysteine $0.1 \%$, D-glucose $0.5 \%$, and $\mathrm{FeCl}_{3} 0.120 \mathrm{mM}$ at $18{ }^{\circ} \mathrm{C}$ for five days. After that, P. salmonis were carefully scraped from bacterial lawn and suspended onto $5 \mathrm{~mL}$ of Tryptic Soy Broth (TSB) (Merck, Darmstadt, Germany) supplemented with NaCl 3 g/L, FBS 2.5\%, L-cysteine 0.05\%, and $\mathrm{FeCl}_{3} 0.01 \mathrm{~g} / \mathrm{L}$ and grown at $18{ }^{\circ} \mathrm{C}$ and $100 \mathrm{rpm}$ for two days [31] prior to the biofilm formation assays. The identified strains were confirmed by PCR assays [30] and 16S rRNA sequencing [32].

\subsection{Quantitative Assessment of P. salmonis Biofilm Formation in Restrictive Liquid Media}

To test different culture conditions for the biofilm formation assays, a basal medium was established using the Marine Broth (MB, BD Difco, Franklin Lakes, NJ, USA) formulation as a reference, which was modified to obtain the following variations of $\mathrm{NaCl}(7.1,24.6$, and $32.1 \mathrm{~g} / \mathrm{L})$ and ferric citrate 
$(0.01,0.08$, and $0.16 \mathrm{mM})$. To evaluate the P. salmonis biofilm formation, the bacteria were cultured in 96-well flat-bottom culture plates (TrueLine, Nippon Genetics, Tokyo, Japan) using $180 \mu \mathrm{L}$ of media containing different $\mathrm{NaCl}$ and ferric citrate concentrations, which were then inoculated with $20 \mu \mathrm{L}$ of bacterial inoculum (McFarland 0.5 standard, $1.5 \times 10^{8} / \mathrm{mL}$ ) and incubated at $18^{\circ} \mathrm{C}$ without agitation for up to eight days. Non-inoculated media $(200 \mu \mathrm{L})$ were used as negative controls. Biofilm formation was quantified after $0,2,4$, and 8 days of culture by the crystal violet (CV) method [33,34] as follows: the culture medium was carefully removed from each well containing the adhered biofilm, which was subsequently washed with phosphate-buffered saline PBS $1 \times(200 \mu \mathrm{L})$ for 5 min to eliminate any non-adhered biofilm or live bacteria. Then, plates were incubated at $37^{\circ} \mathrm{C}$ to fix the adhered biofilm, followed by incubation for $10 \mathrm{~min}$ with crystal violet $(200 \mu \mathrm{L}$ at $3 \mathrm{~g} / \mathrm{mL})$. The $\mathrm{CV}$ solution was then discarded, and the wells were washed with PBS $1 \times$ for $5 \mathrm{~min}$ by repeated pipetting to remove dye excess and dried upside-down at room temperature for $30 \mathrm{~min}$ [35]. Finally, images of the CV stained biofilm obtained for each culture condition were registered using an inverted microscope $(100 \times)$ coupled to an Idu Labcam Microscopy Adapter. Biofilm formation was determined by reading the absorbance of solubilized CV at $595 \mathrm{~nm}$ using a Microplate Reader Synergy ${ }^{\mathrm{TM}} 2$ (BioTek Instruments, Winooski, VT, USA).

To calculate the biofilm production (1), an OD cut-value (ODc) was established as proposed by Stepanovic et al. (2007) [34]. ODc was defined as three standard deviations (SD) above the mean OD of the negative control:

$$
\mathrm{ODc}=\mathrm{ODxn}+3 \times \mathrm{SD} \text {, }
$$

where ODxn is the average OD of the negative control and SD is the standard deviation of the negative control. Thus, the OD value of a tested strain was expressed as the average OD value of the strain or condition reduced by the ODc value. The ODc value was calculated for each microtiter plate separately. If a negative value was obtained, it was presented as zero, while any positive value indicated biofilm production.

\subsection{Planktonic and Sessile P. salmonis Infection in SHK-1 Cells}

To evaluate the effect of planktonic and sessile $P$. salmonis on cellular lysis, an in vitro infection assay was performed in SHK-1 cells. For infection, cells (passage between 61 to 63) were cultured without antibiotics in L-15 medium supplemented with $10 \%$ FBS at $20{ }^{\circ} \mathrm{C}$ in $75 \mathrm{~cm}^{2}$ flasks (Costar, Fisher Scientific, Ottawa, ON, Canada). Cells were seeded into 24-well plates at a concentration of $5 \times 10^{5}$ cell per well for $24 \mathrm{~h}$ at $20^{\circ} \mathrm{C}$ and infected with planktonic and sessile $P$. salmonis at multiplicity of infection (MOI) $10\left(5 \times 10^{6}\right.$ bacteria) of LF-89 and isolate EM-90-like 2 strains. The bacterial inoculum was prepared by growing $P$. salmonis in MB medium $(32.1 \mathrm{gr} / \mathrm{L})$ at $18{ }^{\circ} \mathrm{C}$ for four days in six-well plates (sessile) or in $50 \mathrm{~mL}$ Falcon tubes (planktonic) under moderate agitation (100 rpm). Thus, planktonic and sessile bacteria were collected $(100 \mu \mathrm{L})$ after four days of culture and counted using a LIVE/DEAD BacLight $^{\mathrm{TM}}$ Bacterial Viability Kit (Invitrogen, Molecular Probes, Eugene, OR, USA), following the manufacturer's recommendations. For bacterial quantification, stained bacteria were placed on a Neubauer counting chamber and observed using a fluorescence microscope (Optika, B-1000 series) [36]. Bacteria with yellow-green and orange-red emissions were considered as living and dead (or inactive) bacteria, respectively. Cells were incubated for a further 17 days at $20{ }^{\circ} \mathrm{C}$ and non-infected cells were used as negative controls. Finally, cytotoxicity was evaluated as described by Oliver et al. [37] and RNA was isolated to evaluate immune gene expression.

\subsection{Determination of Cytotoxicity by Lactate Dehydrogenase Assay}

The cell damage induced by P. salmonis in SHK-1 cells was determined by evaluating the liberation of cytosolic enzyme lactate dehydrogenase (LDH) in the cell supernatant using a commercial Cytotoxicity LDH Detection Kit (Takara, Bio Inc., Otsu, Japan). LDH release levels were analyzed in $50 \mu \mathrm{L}$ of cell-free supernatant from each cultured condition. Additionally, the supernatant of cells 
lysed with L-15 medium containing 1\% Triton X-100 was used as a total lysis control (maximum LDH liberation) and the supernatant of uninfected cells was used as control cells. Optical density was measured at $490 \mathrm{~nm}$ and the result was obtained using the Equation (2):

$$
\begin{gathered}
\% \text { of cytotoxicity }=\left[\mathrm{OD}_{490} \text { of }(\text { treated cells }- \text { control cells })\right] /\left[\mathrm{OD}_{490} \text { of }(\text { total lysis }\right. \\
\text { control cells }- \text { control cells })] \times 100
\end{gathered}
$$

\subsection{RNA Purification and Gene Expression Analysis}

Gene expression analysis was carried out through a kinetic study in cells infected with planktonic and sessile P. salmonis, as described above. The infected cells were collected at 2, 4, 6, 12, and $24 \mathrm{~h}$, and total RNA extraction and cDNA synthesis were performed as described by Romero et al. (2012) [38]. LPS $5 \mu \mathrm{g} / \mathrm{mL}$ (Sigma-Aldrich, St. Louis, MO, USA) was used as a positive control for each time point. RNA was purified using the EZNA Total RNA (Omega Bio-Tek, Norcross, GA, USA) including the in-column DNAse I digestion step and the purified RNA was stored at $-80^{\circ} \mathrm{C}$. Reverse transcription was performed using the M-MLV RT Kit (Promega) and the cDNA was stored at $-20{ }^{\circ} \mathrm{C}$. Gene expression was analyzed by qPCR using the Brilliant II SYBR ${ }^{\circledR}$ Green qPCR Master Mix (Agilent Technologies, Santa Clara, CA, USA), and each reaction was performed using $250 \mathrm{nM}$ of primers (Table 1) and $2.5 \mathrm{uL}$ of 1:2 diluted cDNA as a template, in a QuantStudio 3 thermocycler (Applied Biosystems, Waltham, MA, USA). The fold change of gene expression was calculated according to the $2^{-\Delta \Delta C t}$ method [39] using the expression of the elongation factor- $1 \alpha$ (ef- $1 \alpha$ ) as a normalizer, and the expression of all markers in the control condition as a calibrator. The average and standard deviation of the fold change of gene expression were graphed and analyzed with the Tukey's multiple comparison test $(p<0.05)$.

Table 1. Primers used for gene expression analysis.

\begin{tabular}{ccc}
\hline Gene & Sequence $\left(\mathbf{5}^{\prime}-\mathbf{>} \mathbf{3}^{\prime}\right)$ & $\begin{array}{c}\text { GenBank } \\
\text { Accession No. }\end{array}$ \\
\hline$e f-1 \alpha$ & $\begin{array}{c}\text { F-CCCCTCCAGGACGTTTACAAA } \\
\text { R-CACACGGCCCACAGGTACA }\end{array}$ & NM_001123629.1 \\
\hline$i l-1 \beta$ & $\begin{array}{c}\text { F-CAAGCTGCCTCAGGGTCT } \\
\text { R-CGGCACCCTTTAACCTCTCC }\end{array}$ & NM_001123582.1 \\
\hline \multirow{2}{*}{$i l-8$} & $\begin{array}{l}\text { F-GCAACAGCGGTCAGGAGATT } \\
\text { R-TGGAATGATTCCCCTTCTTCA }\end{array}$ & HM162835.1 \\
\hline \multirow{2}{*}{$n f-\kappa b$} & $\begin{array}{l}\text { F-ACCTGGCCATCATTCACCAG } \\
\text { R-TGGTTGAGCTTGTCGAGGAC }\end{array}$ & NM_001173583.1 \\
\hline \multirow{2}{*}{$I \kappa b-\alpha$} & $\begin{array}{l}\text { F-GGAGAGTGAGGAGGAGTGCAT } \\
\text { R-CTGCTTCAATTCTGCCCAAATGTAA }\end{array}$ & XM_014204687.1 \\
\hline
\end{tabular}

\subsection{Statistical Analyses}

Statistical analyses were carried out using GraphPad Prism ${ }^{\circledR} 5$ (GraphPad Software, Inc., La Jolla, CA, USA). The qPCR data were represented as fold change in the gene expression of cells treated with sessile or planktonic bacteria, compared to untreated control cells $(n=4)$. The data differences between the two culture conditions (sessile or planktonic) were analyzed using Tukey's multiple comparison test $(p<0.05)$. The data are depicted as mean \pm SD. Cell viability data are presented as means \pm SD of four biological replicates and the data differences were calculated using the same statistical analysis. 


\section{Results}

\subsection{P. salmonis Biofilm Formation}

To evaluate the effects of iron and salinity on P. salmonis biofilm formation, bacterial growth assays with increasing concentrations of ferric citrate or $\mathrm{NaCl}$ in $\mathrm{MB}$ medium were performed (Figure 1A). In the case of salinity, exposure of $P$. salmonis to high $\mathrm{NaCl}$ concentrations $(26.4 \mathrm{~g} / \mathrm{L}$ and $32.1 \mathrm{~g} / \mathrm{L})$ significantly increased biofilm formation in the LF-89 type strain (Figure 1B) and EM-90-like 1 and 2 (Figure 1D,E) at all evaluated culture times. Regarding iron concentrations, ferric citrate at 0.01, 0.08, and $0.16 \mathrm{mM}$ also increased biofilm production in the LF-89 type strain (Figure 1B) and EM-90-like 1 and 2 (Figure 1D,E). However, these increases were lower compared to the biofilm formation obtained at a higher concentration of $\mathrm{NaCl}$ after four and eight days of culture. It is important to mention that the biofilm production for the Chilean isolate LF-89-like 1 showed the lowest biofilm formation values under all the conditions analyzed in this study (Figure 1A,C). However, the growth of this strain was similar to the other P. salmonis strains used.

A

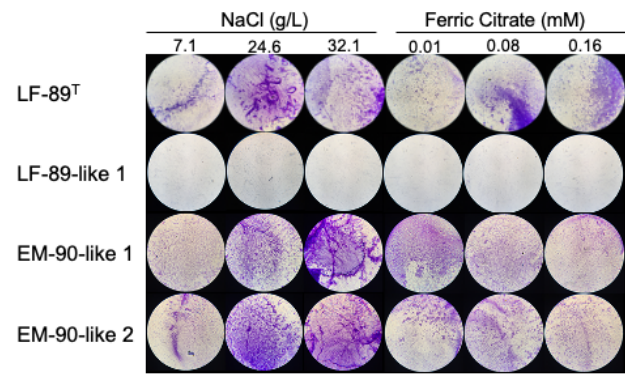

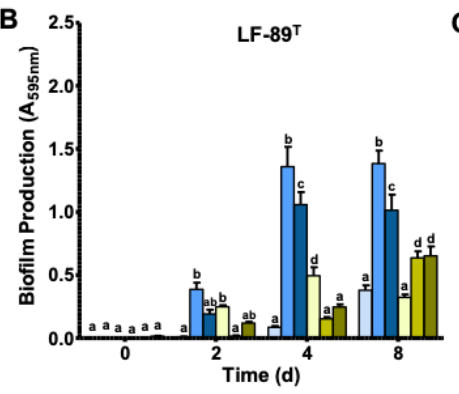

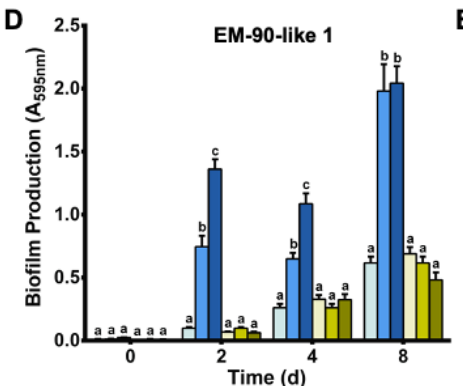

$\square \mathrm{NaCl} 7.1 \mathrm{~g} / \mathrm{L}$

Ferric citrate $0.01 \mathrm{mM}$ Ferric citrate $0.08 \mathrm{mM}$ Ferric citrate $0.16 \mathrm{mM}$

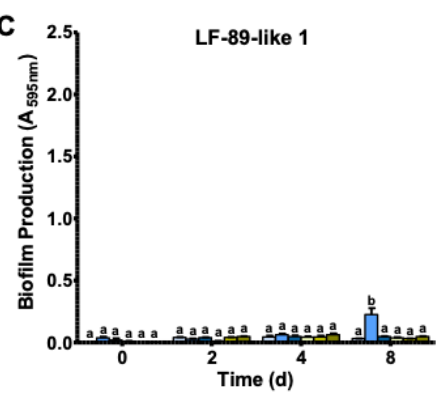

E $\quad 2.51 \quad$ EM-90-like 2

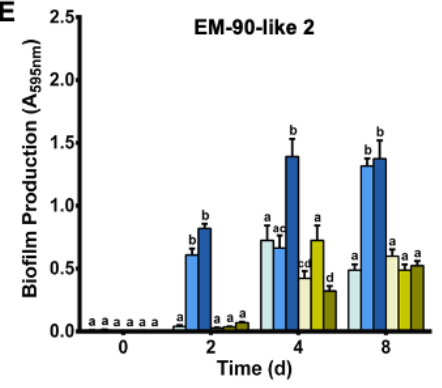

Figure 1. P. salmonis biofilm formation cultured under different $\mathrm{NaCl}$ and ferric citrate concentrations. (A) Representative CV staining of biofilm produced by P. salmonis LF-89 type strain and isolates LF-89-like 1, EM-90-like 1, and EM-like 2 at eight days (100× magnification). Biofilm quantification for P. salmonis LF-89 (B) and isolates LF-89-like 1 (C), EM-90-like 1 (D), and EM-90-like 2 (E) grown for 0, 2, 4 , and 8 days. Values are presented as the mean \pm SEM $(n=5)$. A two-way ANOVA followed by a Tukey HDS was performed to define the differences between media variation. Different letters indicate significant differences $(p<0.05)$. 


\subsection{Planktonic and Sessile P. salmonis Infection in SHK-1 Cells}

To evaluate the in vitro virulence generated by planktonic or sessile bacteria, a kinetic infection assay was performed using SHK-1 cells infected with the P. salmonis LF-89 type strain and EM-90-like 2 in both conditions. The viability of bacterial cells was evaluated by flow cytometry (Figure S1). The results showed independent cytotoxicity profiles for the strains in both conditions (Figure 2). Thus, although the cytotoxic effect of bacteria on cells tended to increase with time after infection with both bacterial strains (except for LF-89 planktonic), it is interesting to note that the effect of planktonic and sessile bacterial conditions was the opposite in the analyzed strains. Specifically, the sessile condition of LF-89 generated a sustained cytopathic effect, with increased cytotoxicity that reached about $60 \%$ after 17 days p.i compared to its planktonic condition, which caused only $10 \%$ of cellular lysis for the same time analyzed (Figure 2). In contrast, the sessile condition of the EM-90-like 2 strain generated only 20\% cytotoxicity while the planktonic condition caused the highest effect in cellular lysis, which reached about $90 \%$ at day 15 post-infection (p.i).

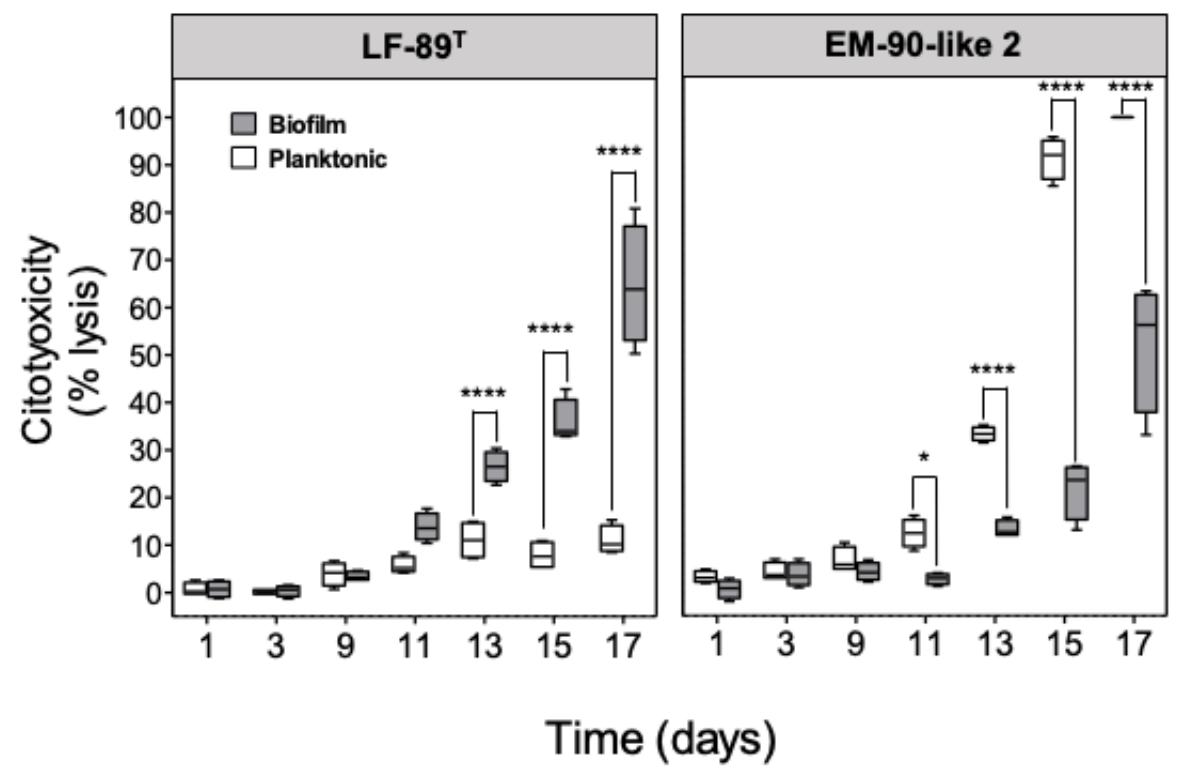

Figure 2. Cytotoxicity assay in SHK-1 cells infected with planktonic and sessile P. salmonis. SHK-1 cells were infected with planktonic or sessile P. salmonis $(\mathrm{MOI}=10)$. Results are expressed as cytotoxicity percentage means \pm standard error of each sample in triplicate. Asterisks indicate significant differences $\left({ }^{*} p<0.05\right.$ and $\left.{ }^{* * * *} p<0.001\right)$.

\subsection{Immune Gene Expression Analysis}

To evaluate the effect of planktonic and sessile conditions on immune gene expression, an infection assay using two bacterial conditions of two different P. salmonis strains on SHK-1 cells was performed. The immune gene expression profile revealed differential modulation of these markers depending on the strain analyzed as well as on the sessile/planktonic bacterial condition (Figure 3). Cells infected with the sessile LF-89 type strain showed higher il-1 $\beta$ expression levels than its planktonic counterpart at 2,4 and $6 \mathrm{~h}$ p.i. (Figure 3A). However, we observed the opposite effect in cells infected with the EM-90-like 2 strain at 2, 4, 6, and $12 \mathrm{~h}$ (Figure 3B). A strong upregulation of il-8 was observed only in cells infected with the EM-90-like 2 strain, and this effect was higher when planktonic bacteria were used (Figure 3D). EM-90-like 2 strain presented increased expression of $n f-k b$ at 2, 4, and $12 \mathrm{~h}$ (Figure 3F). Similarly, a strain-dependent upregulation was also observed for $i \kappa b-\alpha$ gene expression. However, in this case, sessile bacteria generated a lower upregulation (Figure $3 \mathrm{H}$ ). 


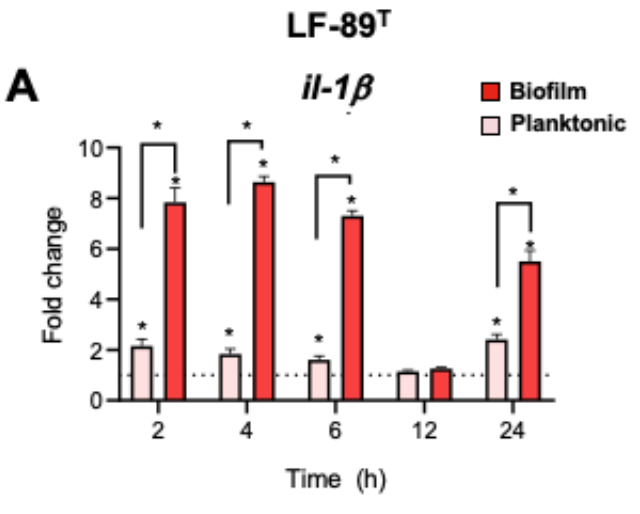

C

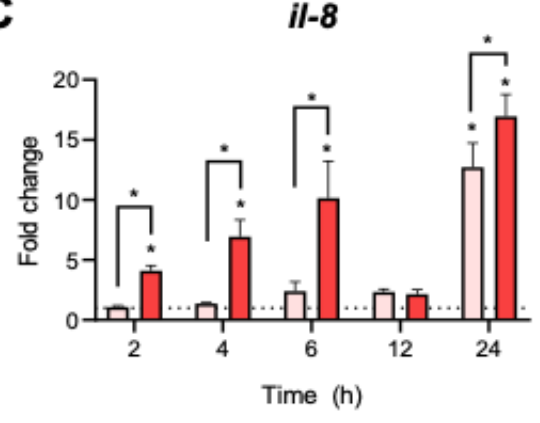

E

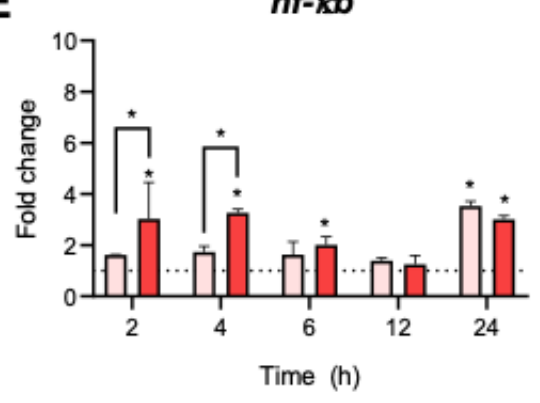

G

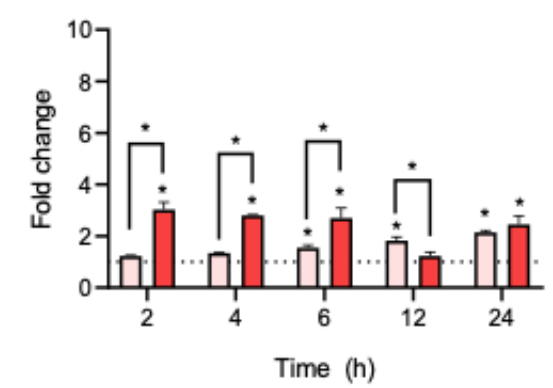

EM-90-like 2
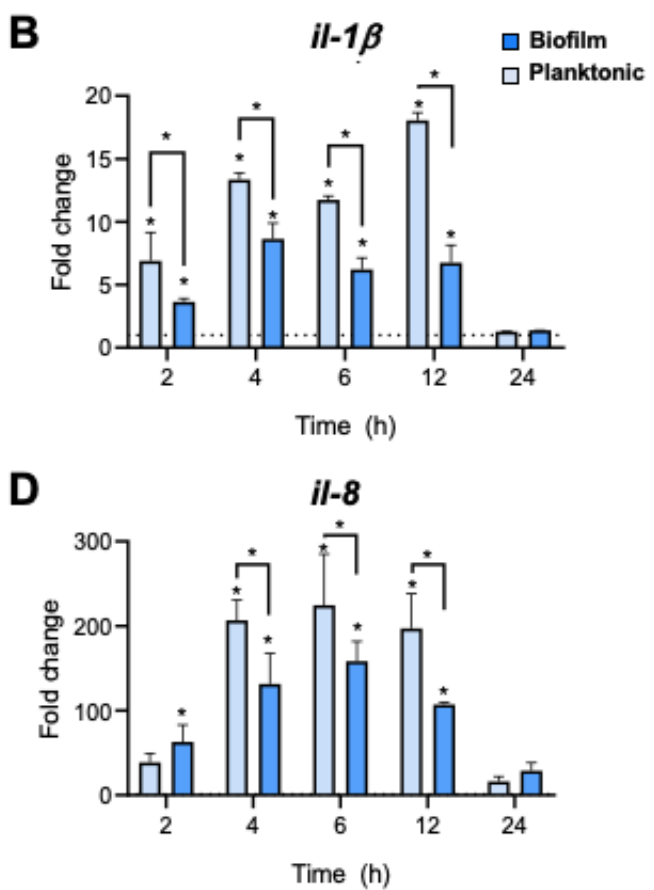

$\mathbf{F}$

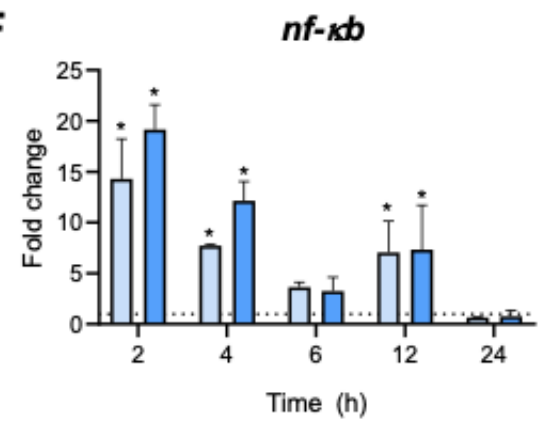

H

$i k-b \alpha$

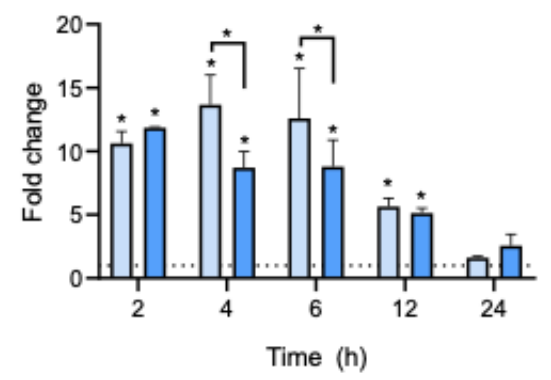

Figure 3. Analysis of the immune gene expression induced by planktonic and sessile P. salmonis. SHK-1 cells were infected with $P$. salmonis LF-89 $9^{\mathrm{T}}$ or EM-90-like 2 strain in planktonic or sessile conditions for $2,4,6,12$, and $24 \mathrm{~h}$, and the mRNA levels of $i l-1 \beta(\mathbf{A}, \mathbf{B}), i l-8(\mathbf{C}, \mathbf{D}), n f-\kappa b(\mathbf{E}, \mathbf{F})$, and $i \kappa b-\alpha(\mathbf{G}, \mathbf{H})$ were analyzed by qRT-PCR. The expression of $e f-1 \alpha$ was used as a normalizer. The graph depicts the average \pm standard deviation of the gene expression fold change. Control cells were used as a calibrator (dotted line). Asterisks above the bars indicate statistically significant differences evaluated using Tukey's multiple comparison test $(p<0.05)$. 


\section{Discussion}

One of the main objectives of this study was to determine the ability of $P$. salmonis to produce biofilm under different $\mathrm{NaCl}$ and ferric citrate concentrations in culture conditions. We found that the LF-89 type strain and the EM-90 type isolates generated biofilms in the modified MB culture medium, predefined as a medium that induces biofilm production in this pathogen [21,35]. An iron source was previously proposed as a necessary element for $P$. salmonis growth in vitro [40,41]. It is for this reason that lower concentrations than those described as optimal were chosen in our study, in order to induce an adverse environment that could trigger a bacterial defense response. However, the three different concentrations of ferric citrate used did generate minor differences in the biofilm production for the strains evaluated. The planktonic LF-89 type strain can grow normally at concentrations between 0.15 to $1 \mathrm{mM}$, while concentrations below $0.01 \mathrm{mM}$ only decrease its growth by $25 \%$ [42]. Taking into account that biofilm formation is considered a mechanism of resistance to stressors [10], the iron concentrations used were possibly not low enough to induce strong biofilm formation in the bacteria in response to suboptimal concentrations. Likewise, we must consider the amount of iron present in both the yeast extract and meat peptone (MB components) at $55.3 \mathrm{ug} / \mathrm{g}$ and $0.004 \%$, respectively, as an extra source for the bacteria. Additionally, the bacterium cultured in vitro lacks the pressure of the host, which, when faced with a bacterial infection, release an entire iron picking machinery as a way to decrease the accessibility of the bacteria to this metabolite [43].

The induced biofilm production in vitro by $P$. salmonis was initially described using MB medium [21,35], which contains a high salt concentration. In this context, our results revealed that $\mathrm{NaCl}$ variations showed greater differences in terms of biofilm formation for the bacteria. Thus, high $\mathrm{NaCl}$ concentrations $(26.6$ and $32.1 \mathrm{~g} / \mathrm{L}$ ), similar to those found in estuarine and marine environments, induced the highest biofilm production in the LF-89 strain and the EM-90 type isolates of P. salmonis. Lannan and Fryer [44] described the bacteria's ability to survive in seawater for long periods of time with free-living bacteria that were found after 40 days in seawater [45]. The influence of salinity on biofilm production has been widely described on a variety of bacteria [46-48]. Although there is no predefined concentration that modulates the highest levels of biofilm production in general for bacteria, different studies have suggested an association between the optimal $\mathrm{NaCl}$ concentration existing in the natural environment of each microorganism and the concentration that increased the biofilm production used for in vitro assays. This is the case of Flavobacterium columnare, a freshwater bacterium responsible for columnaris disease: they produce greater amounts of biofilm in media with $\mathrm{NaCl} 5 \mathrm{~g} / \mathrm{L}$ [24]. In the marine bacteria Vibrio fischeri and Vibrio parahaemolyticus, $\mathrm{NaCl}$ concentrations of $24.8 \mathrm{~g} / \mathrm{L}$ and $20 \mathrm{~g} / \mathrm{L}$, respectively, induced the highest biofilm production [49,50]. Interestingly, the salt concentrations where these bacteria produced higher biofilm levels were similar to those concentrations in which the P. salmonis strains evaluated in our study produced higher biofilm levels. In this way, the in vitro results observed in this study could be extrapolated as an adaptive survival and persistence mechanism involving the development of extracellular aggregates by the bacteria, when submitted to adverse marine conditions.

From the results presented above, the next step to follow was to determine if the planktonic and sessile condition of $P$. salmonis had differential cytopathic effects in SHK-1 cells. Indeed, the infected cells showed differential damage (Figure 2), which can be influenced by both the planktonic or sessile condition as well as the bacterial strains used. This result is in agreement with what was described by Levipán et al. [29], who reported different cytotoxicity degrees between P. salmonis LF-89 and EM-90 isolates in their sessile and planktonic state. Most of the studies aiming to characterize $P$. salmonis virulence, pathogenicity, antimicrobial resistance, and induction of the immune responses are routinely conducted using planktonic bacteria or colonies suspended from plaque growth, inoculating SHK-1, ASK [51], and RTS11 [52] fish cell lines. SHK-1 cells are derived from leukocytes that have some of the properties of a macrophages [53], which are activated by several pathogen associated molecular patterns (PAMPs) such as lipopolysaccharides (LPS) present in bacterial surface and which are recognized by TOLL-like receptors (TLRs) present in these cells. In this way, they are capable of 
secreting proinflammatory cytokines. Likewise, the SHK-1 cells are able to phagocytose several fish pathogens such as Aeromonas salmonicida [53], ISA virus [54], and infectious pancreatic necrosis virus (IPNV) [55], among others, for the subsequent pathogen destruction. Likewise, Olavarría et al. [56] described that the macrophage activation by LPS promotes the protein kinase $\mathrm{C}$ activation, which in turn phosphorylates p47phox, leading to NADPH oxidase activation and reactive oxygen species generation. Thus, these cells facilitate the infection of $P$. salmonis by phagocytosis and intracellular proliferation of the bacteria. In the case of SHK-1 cells, the cytotoxicity of $P$. salmonis starts around day 5 p.i., depending on the strain and MOI used [37,57,58]. Different studies have described P. salmonis cytotoxicity in SHK-1 cells $[37,41,58,59]$, indicating an apparent dependency between cytotoxicity and the number of bacteria, and more importantly, the number of live bacteria in the inoculum used. In this sense, there could be an important difference in the inoculum used in our study versus the one previously used by Levipán et al. [29], generating a higher toxicity in a shorter time. Another important factor to consider is the type of strains used for both studies. In this context, it is known that the bacterial virulence is different, especially in the in vitro systems. This was similar in the case of $P$. salmonis, which has differential characteristics in protein content, susceptibility to antibiotics, and OMV production and virulence, among others. Our results showed a delay in cell cytotoxicity caused by the bacteria, both in its planktonic and sessile form, beginning instead at 10 days p.i. Considering the $P$. salmonis cellular pathogenesis, these differences may be due to multiple factors that are intrinsic to the bacterium, related to its metabolic state, expression of virulence factors, its ability for survival and intracellular multiplication [1,59], and all this in turn may be conditioned by their planktonic and/or sessile state. In the case of Legionella pneumophila, its sessile state replicates in bone marrow-derived macrophage cells (BMDMs) with a greater capacity compared to its planktonic counterpart, also inducing lesser cell death in infected macrophages, similar to that observed for the EM-90 isolate used in this study. Likewise, planktonic L. pneumophila was rapidly sent to the lysosomes for degradation, while most biofilm-derived bacteria remained inside a vacuole [60]. This intracellular survival strategy has also been described in P. salmonis and could be related to a potential contribution of the biofilm in the infecting bacteria $[59,61,62]$, revealing different degrees of cytotoxicity, a particular aspect that has not yet been studied in P. salmonis. Interestingly, studies carried out by Baldassarri et al. [63], revealed that Enterococcus faecalis strains in a sessile state showed greater survival within macrophages than mutant isogenic strains for exopolysaccharide production. Similarly, infection studies in RAW264.7 macrophages and JAWS II dendritic cells with planktonic and sessile E. faecalis revealed that sessile bacteria had similar or higher infection levels than their planktonic counterparts with one of the strains used showing higher survival inside macrophages than the others at $24 \mathrm{~h}$, suggesting that sessile E. faecalis could be better adapted and overcome host defenses associated with a decreased cellular response [64]. In the case of $P$. salmonis, our results revealed marked cytotoxicity differences between the planktonic and sessile condition, and surprisingly, this cytotoxicity pattern contrasted between the LF-89 strain and the EM-90 type isolate. These findings suggest that the differences could be due to the absence or differential expression of virulence factors and a variability in secreted molecules by each bacterium during biofilm formation, consequently future studies involving these subjects may cast a new light on the differences found in P. salmonis LF- 89 and EM-90 in its sessile and planktonic state. On the other hand, the differences in the results observed in this study compared to the results obtained by Levipán et al. [29], may be due to the use of different $P$. salmonis strains and, obviously, to the time at which the inoculum was made. Unfortunately, in both studies only one inoculum was used for experimental purposes, so it could not be compared whether this was due to time or the strains used. In light of our results, we can conclude that there would be no correlation between the cytotoxicity generated in SHK-1 cells by the sessile and planktonic condition of the same strain. However, more studies are needed to have a more global idea of the virulence of the P. salmonis biofilm.

Although it has been previously shown in vitro and in vivo that the virulence of planktonic P. salmonis is partly related to its ability to modulate the immune cell response and the host immune system [52,65], until now, no studies have compared the transcriptional response of immune genes 
against a planktonic and sessile P. salmonis infection. The NF- $\mathrm{kB}$ signaling pathway is an attractive target for exploitation by microbial pathogens in order to modulate host cell events, as activation of NF- $\mathrm{kB}$ is such a rapid response. NF- $\mathrm{kB}$ complexes are transferred to the nucleus within minutes after exposure to a pathogen or PAMPs. This transcription factor resides in the cytosol in an inactive form complexed to the chaperone protein inhibitory of NF-kB and IkB- $\alpha$. Upon phosphorylation, IKB- $\alpha$ dissociates from the complex and NF-kB can enter the nucleus to bind the NF-kB responsive element in the promoter region of target genes. The participation of both NF-kB and IkB- $\alpha$ in the cellular responses to bacterial biofilm components have been extensively studied by transcriptional and functional analysis, being key markers to access the evasion and modulation mechanisms in the functionality of phagocytic cells. Thus, the expression of $i l-1 \beta$ and $i l-8$ is regulated by NF- $\mathrm{KB}[66,67]$. Furthermore, the immunomodulatory effect of sessile bacteria on the activity of phagocytes has been verified through the expression of cytokine encoding genes, and among them are $i l-1 \beta$ and $i l-8[68,69]$. Our results revealed a differential modulation on immune markers, dependent on the P. salmonis strain, and in some cases on the sessile/planktonic state of the bacterium (Figure 3). Overall, a significant and more attenuated response was observed for SHK-1 cells infected with sessile P. salmonis than to their planktonic counterpart. In the case of the LF- 89 strain type, sessile bacterium generated the greatest increases in the expression of $i l-1 \beta, i l-8, n f-k b$, and $i k b-\alpha$ genes compared to the planktonic form. This effect was observed only during the first hours after infection, and then returned to baseline levels after $24 \mathrm{~h}$ in both conditions and for all the genes analyzed. In this sense, the differential modulation of proinflammatory cytokines such as $i l-1 \beta, i l-12, i l-6$, and $t n f-\alpha$ were previously described in mice purified peritoneal macrophages treated with eight different isolates of sessile P. aeruginosa [70]. In the case of Staphylococcus pseudintermedius, RAW 264.7 cells macrophages treated with biofilm purified from this bacterium induced high responses of $i l-1 \beta$ and $i l-6$, which was attributed to the interaction of the cells with biofilm protein components, activating the signaling pathway of Toll and NF-kB receptors [71]. These results demonstrate that the interaction of the sessile form of LF-89 with SHK-1 cells was different from that obtained with the planktonic form, probably due to specific components in its exopolysaccharide matrix, which could increase the expression of the evaluated immune genes, concomitant to increased cytotoxicity of this strain in the cell line. However, bacterial sessile status is classically associated with a decreased cellular response and expression of host immune genes, which was observed in the expression levels of $i l-1 \beta, i l-8$, and $i k b-\alpha(4,6$, and $12 \mathrm{hpi}$ ) that were significantly lower in cells infected with the sessile bacteria in EM-90 isolate. This immunosuppressive pattern was also described for E. faecalis in RAW264.7 cells infected with two strains of the bacterium in their sessile state, where decreases in tnf- $\alpha$ and il-6 expression was also concomitant with increased intracellular survival of the bacteria, compared to its planktonic state [64]. Similarly, K. pneumoniae in biofilm mode elicited a minimal phagocytic response and cytokine expression by RAW 264.7 macrophages [72], which was confirmed in vivo by the infection of rats with sessile and dispersed bacteria from biofilm, which caused a lower innate immune response in the lungs than planktonic bacteria. Collectively, the findings of this study suggest that the increased ability of K. pneumoniae biofilm scattered cells to achieve surface colonization and subvert the host's immune response grants them substantial advantages in the early stages of the infection process [73]. Likewise, some bacterial species present dysregulated proinflammatory cytokine expression during infection with sessile bacteria, which could be attributed to the modulation of the Toll-like receptor signaling pathway. Thus, S. aureus significantly reduced the bactericidal and proinflammatory response of RAW 264.7 cells, associated with the attenuation of $n f-k b$ activation [74]. This is in accordance with S. epidermidis, which presented decreased production of $i l-1 \beta$ and $i l-6$ as well as altered phagocytosis as an immune escape strategy in J774A.1 macrophages [75]. Planktonic and sessile P. salmonis LF-89 and EM-90 modulated the expression of $n f-k b$ and its inhibitory subunit $i k b-\alpha$ in agreement with the modulation of several cytokines during the infectious process of $P$. salmonis, which has been previously described [65,76]. In this sense, the expression of immunity genes evaluated indicated increments on $i l-1 \beta$, il-8, and $i \kappa b-\alpha$ genes during the $24 \mathrm{hpi}$, which later resulted in an increased cytotoxicity produced 
by the bacteria. Additionally, Rozas et al. [77] reported an increase in the expression of $i l-1 \beta, i l-8$, tnf- $\alpha$, and ifn-r genes in the cohabiting fish kidneys at day 28 after being exposed to Trojan fish. It is important to mention that this finding was described in fish infected with both LF-89 and EM-90 strains, and the mortality in both groups began after the increment in the immune gene expression, between days 45 and 42 post challenge, respectively. Additionally, the increased $i \kappa b-\alpha$ transcript levels in cells infected with planktonic EM-90 suggest increased activation of the $n f-k b$ pathway and therefore, increased expression of proinflammatory cytokines $[78,79]$. Interestingly, several molecular biofilm components, specifically EPS, are important modulators of the host's immune response against bacterial infections [69]. However, until now, the P. salmonis biofilm composition has not been described, nor are there any studies evaluating the effect of biofilm production by $P$. salmonis during in vitro or in vivo infection, nor its association with the immune response. According to our results, immune genes are differentially modulated in a manner that is directly proportional between the cytotoxicity of the planktonic or sessile bacteria and the increments in the expression of $i l-1 \beta, i l-8$, and $i \kappa b-\alpha$ genes. The $P$. salmonis sessile and planktonic conditions modulated bacterial virulence in SHK-1 cells. Levipán et al. (2020) [29] observed that $P$. salmonis forms viable, stable, and fish skin-mucus tolerant biofilms on abiotic surfaces in aquaculture. Thus, the biofilm produced by $P$. salmonis could be considered an important virulence factor as well as a good candidate for the future development of new and better antimicrobial agents. In this sense, the anti-biofilm activity is based on inhibiting bacterial adhesion to surfaces, the disruption of the biofilm architecture during its maturation process, and the interference with the quorum sensing system [80]. Additionally, gene expression regulation by planktonic and sessile P. salmonis could be considered a key component that affects the immune response of fish. The study of the antigenic components in biofilm opens up new possibilities for the development and application of biofilm-based vaccine prototypes as well as a prophylactic strategy against bacterial diseases, which has already been explored in tilapia and carp with promising results $[81,82]$.

\section{Conclusions}

This study determined the biofilm production levels of four strains belonging to both P. salmonis genogroups. Additionally, we determined the differential virulence of these strains in their two planktonic and sessile stages in SHK-1 cells as well as the immune gene expression induced by these two bacterial conditions. In conclusion, these results demonstrate that the planktonic or sessile condition of $P$. salmonis generated a differential pattern of virulence and gene expression and this is, apparently, dependent on each strain and bacterial condition evaluated. While the specific role of biofilm in virulence was not clearly elucidated in this study, the presence and abundance of biofilm suggest an important biological function by interacting with host proteins and modulating its immune response, and thus affecting bacterial pathogenesis. However, further studies are needed to clarify the presence of $P$. salmonis biofilm during infection, and also to establish the specific role of the components of this biofilm, especially regarding possible functions inside the host cells.

Supplementary Materials: The following are available online at http://www.mdpi.com/2076-2607/8/10/1609/s1 , Figure S1: Cell viability of planktonic and sessile P. salmonis.

Author Contributions: N.S., M.V., and T.P. performed most experiments. A.Y., J.F., and R.E. participated in the writing of the original draft. R.G.-S. performed some of the experiments. C.O. and A.R. planned the experiments and participated in the correction as well as in the final writing of the manuscript. All authors have read and agreed to the published version of the manuscript.

Funding: This research was funded by the Agencia Nacional de Investigación y Desarrollo (Grant numbers FONDECYT 1171357 to A.R., FONDECYT 11180994 to C.O., FONDAP INCAR 15110027) and by the Vicerrectoría de Investigación, Desarrollo y Creación Artística (VIDCA) of the Universidad Austral de Chile.

Acknowledgments: The authors also thank Fraunhofer Chile Research for providing the P. salmonis LF-89 type strain used in this study and National Fisheries and Aquaculture Service (SERNAPESCA) FIE-2015-V014 Grant number 122929 for providing the P. salmonis LF89 and EM90 isolates.

Conflicts of Interest: The authors declare no conflicts of interest. The funding institutions played no role in the design of the study, in the collection, analyses, or interpretation of data, in the writing of the manuscript, or in 
the decision to publish the results. The authors declare that the research was conducted in the absence of any commercial or financial relationships that could be construed as a potential conflict of interest.

\section{References}

1. Figueroa, J.; Cárcamo, J.; Yañez, A.; Olavarria, V.; Ruiz, P.; Manríquez, R.; Muñoz, C.; Romero, A.; Avendaño-Herrera, R. Addressing viral and bacterial threats to salmon farming in Chile: Historical contexts and perspectives for management and control. Rev. Aquac. 2019, 11, 299-324. [CrossRef]

2. Bravo, C.; Martinez, V. Whole-genome comparative analysis of the pathogen Piscirickettsia salmonis. Vet. Microbiol. 2016, 196, 36-43. [CrossRef] [PubMed]

3. Nourdin-Galindo, G.; Sanchez, P.; Molina, C.F.; Espinoza-Rojas, D.A.; Oliver, C.; Ruiz, P.; Vargas-Chacoff, L.; Carcamo, J.G.; Figueroa, J.E.; Mancilla, M.; et al. Comparative Pan-Genome Analysis of Piscirickettsia salmonis Reveals Genomic Divergences within Genogroups. Front. Cell Infect. Microbiol. 2017, 7, 459. [CrossRef] [PubMed]

4. Cortés, M.; Sánchez, P.; Ruiz, P.; Haro, R.; Sáez, J.; Sánchez, F.; Hernández, M.; Oliver, C.; Yáñez, A.J. In vitro expression of Sec-dependent pathway and type 4B secretion system in Piscirickettsia salmonis. Microb. Pathog. 2017, 110, 586-593. [CrossRef] [PubMed]

5. Gomez, F.A.; Tobar, J.A.; Henriquez, V.; Sola, M.; Altamirano, C.; Marshall, S.H. Evidence of the Presence of a Functional Dot/Icm Type IV-B Secretion System in the Fish Bacterial Pathogen Piscirickettsia salmonis. PLoS ONE 2013, 8, e54934. [CrossRef]

6. Mancilla, M.; Saavedra, J.; Grandon, M.; Tapia, E.; Navas, E.; Grothusen, H.; Bustos, P. The mutagenesis of a type IV secretion system locus of Piscirickettsia salmonis leads to the attenuation of the pathogen in Atlantic salmon, Salmo salar. J. Fish Dis. 2018, 41, 625-634. [CrossRef]

7. Oliver, C.; Valenzuela, K.; Hernandez, M.; Sandoval, R.; Haro, R.E.; Avendano-Herrera, R.; Carcamo, J.G.; Villar, M.T.; Artigues, A.; Garduno, R.; et al. Characterization and pathogenic role of outer membrane vesicles produced by the fish pathogen Piscirickettsia salmonis under in vitro conditions. Vet. Microbiol. 2016, 184, 94-101. [CrossRef]

8. Oliver, C.; Hernandez, M.A.; Tandberg, J.I.; Valenzuela, K.N.; Lagos, L.X.; Haro, R.E.; Sanchez, P.; Ruiz, P.A.; Sanhueza-Oyarzun, C.; Cortes, M.A.; et al. The Proteome of Biologically Active Membrane Vesicles from Piscirickettsia salmonis LF-89 Type Strain Identifies Plasmid-Encoded Putative Toxins. Front. Cell Infect. Microbiol. 2017, 7, 420. [CrossRef]

9. Chen, T.; Dong, G.; Zhang, S.; Zhang, X.; Zhao, Y.; Cao, J.; Zhou, T.; Wu, Q. Effects of iron on the growth, biofilm formation and virulence of Klebsiella pneumoniae causing liver abscess. BMC Microbiol. 2020, 20, 36. [CrossRef]

10. Flemming, H.C.; Wingender, J.; Szewzyk, U.; Steinberg, P.; Rice, S.A.; Kjelleberg, S. Biofilms: An emergent form of bacterial life. Nat. Rev. Microbiol. 2016, 14, 563-575. [CrossRef]

11. Hostacka, A.; Ciznar, I.; Stefkovicova, M. Temperature and $\mathrm{pH}$ affect the production of bacterial biofilm. Folia Microbiol. (Prague) 2010, 55, 75-78. [CrossRef] [PubMed]

12. Singh, S.; Singh, S.K.; Chowdhury, I.; Singh, R. Understanding the Mechanism of Bacterial Biofilms Resistance to Antimicrobial Agents. Open Microbiol. J. 2017, 11, 53-62. [CrossRef] [PubMed]

13. Rabin, N.; Zheng, Y.; Opoku-Temeng, C.; Du, Y.; Bonsu, E.; Sintim, H.O. Biofilm formation mechanisms and targets for developing antibiofilm agents. Future Med. Chem. 2015, 7, 493-512. [CrossRef]

14. Epstein, A.K.; Pokroy, B.; Seminara, A.; Aizenberg, J. Bacterial biofilm shows persistent resistance to liquid wetting and gas penetration. Proc. Natl. Acad. Sci. USA 2011, 108, 995-1000. [CrossRef] [PubMed]

15. Tote, K.; Horemans, T.; Vanden Berghe, D.; Maes, L.; Cos, P. Inhibitory effect of biocides on the viable masses and matrices of Staphylococcus aureus and Pseudomonas aeruginosa biofilms. Appl. Environ. Microbiol. 2010, 76, 3135-3142. [CrossRef]

16. Isiaku, A.I.; Sabri, M.Y.; Ina-Salwany, M.Y.; Hassan, M.D.; Tanko, P.N.; Bello, M.B. Biofilm is associated with chronic streptococcal meningoencephalitis in fish. Microb. Pathog. 2017, 102, 59-68. [CrossRef]

17. Thuptimdang, P.; Limpiyakorn, T.; McEvoy, J.; Pruss, B.M.; Khan, E. Effect of silver nanoparticles on Pseudomonas putida biofilms at different stages of maturity. J. Hazard. Mater. 2015, 290, 127-133. [CrossRef]

18. Jefferson, K.K. What drives bacteria to produce a biofilm? FEMS Microbiol. Lett. 2004, 236, 163-173. [CrossRef] 
19. Nguyen, U.T.; Burrows, L.L. DNase I and proteinase K impair Listeria monocytogenes biofilm formation and induce dispersal of pre-existing biofilms. Int. J. Food Microbiol. 2014, 187, 26-32. [CrossRef]

20. Qi, L.; Li, H.; Zhang, C.; Liang, B.; Li, J.; Wang, L.; Du, X.; Liu, X.; Qiu, S.; Song, H. Relationship between Antibiotic Resistance, Biofilm Formation, and Biofilm-Specific Resistance in Acinetobacter baumannii. Front. Microbiol. 2016, 7, 483. [CrossRef]

21. Marshall, S.H.; Gomez, F.A.; Ramirez, R.; Nilo, L.; Henriquez, V. Biofilm generation by Piscirickettsia salmonis under growth stress conditions: A putative in vivo survival/persistence strategy in marine environments. Res. Microbiol. 2012, 163, 557-566. [CrossRef] [PubMed]

22. Gonzalez-Contreras, A.; Magarinos, B.; Godoy, M.; Irgang, R.; Toranzo, A.E.; Avendano-Herrera, R. Surface properties of Streptococcus phocae strains isolated from diseased Atlantic salmon, Salmo salar L. J. Fish Dis. 2011, 34, 203-215. [CrossRef]

23. Ruiz, P.; Poblete, M.; Yanez, A.J.; Irgang, R.; Toranzo, A.E.; Avendano-Herrera, R. Cell-surface properties of Vibrio ordalii strains isolated from Atlantic salmon Salmo salar in Chilean farms. Dis. Aquat. Organ. 2015, 113, 9-23. [CrossRef] [PubMed]

24. Cai, W.; De La Fuente, L.; Arias, C.R. Biofilm formation by the fish pathogen Flavobacterium columnare: Development and parameters affecting surface attachment. Appl. Environ. Microbiol. 2013, 79, 5633-5642. [CrossRef] [PubMed]

25. Sundell, K.; Wiklund, T. Effect of biofilm formation on antimicrobial tolerance of Flavobacterium psychrophilum. J. Fish. Dis. 2011, 34, 373-383. [CrossRef] [PubMed]

26. Cai, W.; Arias, C.R. Biofilm Formation on Aquaculture Substrates by Selected Bacterial Fish Pathogens. J. Aquat. Anim. Health 2017, 29, 95-104. [CrossRef]

27. Coquet, L.; Cosette, P.; Junter, G.-A.; Beucher, E.; Saiter, J.-M.; Jouenne, T. Adhesion of Yersinia ruckeri to fish farm materials: Influence of cell and material surface properties. Colloid Surf. B 2002, 26, 373-378. [CrossRef]

28. King, R. The Presence of Bacterial Pathogens in Recirculating Aquaculture System Biofilms and their Response to Various Sanitizers. Ph.D. Thesis, Faculty of the Virginia Polytechnic Institute and State University, Blacksburg, VA, USA, 2001.

29. Levipan, H.A.; Irgang, R.; Yáñez, A.; Avendaño-Herrera, R. Improved understanding of biofilm development by Piscirickettsia salmonis reveals potential risks for the persistence and dissemination of piscirickettsiosis. Sci. Rep. 2020, 10, 12224. [CrossRef]

30. Karatas, S.; Mikalsen, J.; Steinum, T.M.; Taksdal, T.; Bordevik, M.; Colquhoun, D.J. Real time PCR detection of Piscirickettsia salmonis from formalin-fixed paraffin-embedded tissues. J. Fish Dis. 2008, 31, 747-753. [CrossRef]

31. Vera, T.; Isla, A.; Cuevas, A.; Figueroa, J. A new liquid medium for the pathogen Piscirickettsia salmonis. Arch. Med. Vet. 2012, 44, 273-277. [CrossRef]

32. Contreras-Lynch, S.; Olmos, P.; Vargas, A.; Figueroa, J.; Gonzalez-Stegmaier, R.; Enriquez, R.; Romero, A. Identification and genetic characterization of Piscirickettsia salmonis in native fish from southern Chile. Dis. Aquat. Organ. 2015, 115, 233-244. [CrossRef] [PubMed]

33. Christensen, G.D.; Simpson, W.A.; Younger, J.J.; Baddour, L.M.; Barrett, F.F.; Melton, D.M.; Beachey, E.H. Adherence of coagulase-negative staphylococci to plastic tissue culture plates: A quantitative model for the adherence of staphylococci to medical devices. J. Clin. Microbiol. 1985, 22, 996-1006. [CrossRef]

34. Stepanović, S.; Vuković, D.; Hola, V.; Di Bonaventura, G.; Djukić, S.; Cirković, I.; Ruzicka, F. Quantification of biofilm in microtiter plates: Overview of testing conditions and practical recommendations for assessment of biofilm production by staphylococci. APMIS 2007, 115, 891-899. [CrossRef] [PubMed]

35. Albornoz, R.; Valenzuela, K.; Pontigo, J.P.; Sanchez, P.; Ruiz, P.; Avendano-Herrera, R.; Romero, A.; Oliver, C.; Yanez, A. Identification of chemotaxis operon cheYZA and cheA gene expression under stressful conditions in Piscirickettsia salmonis. Microb. Pathog. 2017, 107, 436-441. [CrossRef] [PubMed]

36. McBain, A.J.; Bartolo, R.G.; Catrenich, C.E.; Charbonneau, D.; Ledder, R.G.; Rickard, A.H.; Symmons, S.A.; Gilbert, P. Microbial Characterization of Biofilms in Domestic Drains and the Establishment of Stable Biofilm Microcosms. Appl. Environ. Microbiol. 2003, 69, 177-185. [CrossRef]

37. Oliver, C.; Valenzuela, K.; Silva, H.; Haro, R.E.; Cortes, M.; Sandoval, R.; Pontigo, J.P.; Alvarez, C.; Figueroa, J.E.; Avendano-Herrera, R.; et al. Effectiveness of egg yolk immunoglobulin against the intracellular salmonid pathogen Piscirickettsia salmonis. J. Appl. Microbiol. 2015, 119, 365-376. [CrossRef] [PubMed] 
38. Romero, A.; Manríquez, R.; Alvarez, C.; Gajardo, C.; Vásquez, J.; Kausel, G.; Monrás, M.; Olavarría, V.H.; Yáñez, A.; Enríquez, R.; et al. Prolactin-releasing peptide is a potent mediator of the innate immune response in leukocytes from Salmo salar. Vet. Immunol. Immunopathol. 2012, 147, 170-179. [CrossRef]

39. Pfaffl, M.W. A new mathematical model for relative quantification in real-time RT-PCR. Nucleic Acids Res. 2001, 29, e45. [CrossRef]

40. Makrinos, D.L.; Bowden, T.J. Growth characteristics of the intracellular pathogen, Piscirickettsia salmonis, in tissue culture and cell-free media. J. Fish Dis. 2017, 40, 1115-1127. [CrossRef]

41. Yanez, A.J.; Valenzuela, K.; Silva, H.; Retamales, J.; Romero, A.; Enriquez, R.; Figueroa, J.; Claude, A.; Gonzalez, J.; Avendano-Herrera, R.; et al. Broth medium for the successful culture of the fish pathogen Piscirickettsia salmonis. Dis. Aquat. Organ. 2012, 97, 197-205. [CrossRef]

42. Calquin, P.; Ruiz, P.; Oliver, C.; Sanchez, P.; Haro, R.; Oliva, H.; Vargas-Chacoff, L.; Avendano-Herrera, R.; Yanez, A.J. Physiological evidence that Piscirickettsia salmonis produces siderophores and uses iron from different sources. J. Fish Dis. 2018, 41, 553-558. [CrossRef] [PubMed]

43. Bury, N.; Grosell, M. Iron acquisition by teleost fish. Comp. Biochem. Physiol. Part C Toxicol. Pharmacol. 2003, 135, 97-105. [CrossRef]

44. Lannan, C.N.; Fryer, J.L. Extracellular Survival of Piscirickettsia salmonis. J. Fish Dis. 1994, 17, 545-548. [CrossRef]

45. Olivares, J.; Marshall, S.H. Determination of minimal concentration of Piscirickettsia salmonis in water columns to establish a fallowing period in salmon farms. J. Fish Dis. 2010, 33, 261-266. [CrossRef] [PubMed]

46. Caruso, G. Microbial Colonization in Marine Environments: Overview of Current Knowledge and Emerging Research Topics. J. Mar. Sci. Eng. 2020, 8, 78. [CrossRef]

47. Chiu, J.M.Y.; Thiyagarajan, V.; Tsoi, M.M.Y.; Qian, P.Y. Qualitative and quantitative changes in marine biofilms as a function of temperature and salinity in summer and winter. Biofilms 2005, 2, 183-195. [CrossRef]

48. Gu, L.; Chen, Q.; Guo, A.; Liu, W.; Ruan, Y.; Zhang, X.; Nou, X. Differential Effects of Growth Medium Salinity on Biofilm Formation of Two Salmonella enterica Strains. J. Food Prot. 2020, 83, 196-203. [CrossRef]

49. Marsden, A.E.; Grudzinski, K.; Ondrey, J.M.; DeLoney-Marino, C.R.; Visick, K.L. Impact of Salt and Nutrient Content on Biofilm Formation by Vibrio fischeri. PLoS ONE 2017, 12, e0169521. [CrossRef]

50. Mizan, M.F.R.; Ashrafudoulla, M.; Sadekuzzaman, M.; Kang, I.; Ha, S.-D. Effects of NaCl, glucose, and their combinations on biofilm formation on black tiger shrimp (Penaeus monodon) surfaces by Vibrio parahaemolyticus. Food Control. 2018, 89, 203-209. [CrossRef]

51. Smith, P.A.; Diaz, F.E.; Rojas, M.E.; Diaz, S.; Galleguillos, M.; Carbonero, A. Effect of Piscirickettsia salmonis inoculation on the ASK continuous cell line. J. Fish Dis. 2015, 38, 321-324. [CrossRef]

52. Alvarez, C.A.; Gomez, F.A.; Mercado, L.; Ramirez, R.; Marshall, S.H. Piscirickettsia salmonis Imbalances the Innate Immune Response to Succeed in a Productive Infection in a Salmonid Cell Line Model. PLoS ONE 2016, 11, e0163943. [CrossRef] [PubMed]

53. Dannevig, B.H.; Brudeseth, B.E.; Gjøen, T.; Rode, M.; Wergeland, H.I.; Evensen, Ø.; Press, C.M. Characterisation of a long-term cell line (SHK-1) developed from the head kidney of Atlantic salmon (Salmo salar L.). Fish Shellfish Immunol. 1997, 7, 213-226. [CrossRef]

54. Dannevig, B.H.; Falk, K.; Namork, E. Isolation of the causal virus of infectious salmon anaemia (ISA) in a long-term cell line from Atlantic salmon head kidney. J. Gen. Virol. 1995, 76, 1353-1359. [CrossRef] [PubMed]

55. Levicán-Asenjo, J.; Soto-Rifo, R.; Aguayo, F.; Gaggero, A.; Leon, O. Salmon cells SHK-1 internalize infectious pancreatic necrosis virus by macropinocytosis. J. Fish Dis. 2019, 42, 1035-1046. [CrossRef]

56. Olavarría, V.H.; Gallardo, L.; Figueroa, J.E.; Mulero, V. Lipopolysaccharide primes the respiratory burst of Atlantic salmon SHK-1 cells through protein kinase C-mediated phosphorylation of p47phox. Dev. Comp. Immunol. 2010, 34, 1242-1253. [CrossRef] [PubMed]

57. Hernandez, A.J.; Romero, A.; Gonzalez-Stegmaier, R.; Dantagnan, P. The effects of supplemented diets with a phytopharmaceutical preparation from herbal and macroalgal origin on disease resistance in rainbow trout against Piscirickettsia salmonis. Aquaculture 2016, 454, 109-117. [CrossRef]

58. Oliver, C.; Sánchez, P.; Valenzuela, K.; Hernández, M.; Pontigo, J.P.; Rauch, M.C.; Garduño, R.A.; Avendaño-Herrera, R.; Yáñez, A.J. Subcellular Location of Piscirickettsia salmonis Heat Shock Protein 60 (Hsp60) Chaperone by Using Immunogold Labeling and Proteomic Analysis. Microorganisms 2020, 8, 117. [CrossRef] 
59. Zuniga, A.; Aravena, P.; Pulgar, R.; Travisany, D.; Ortiz-Severin, J.; Chavez, F.P.; Maass, A.; Gonzalez, M.; Cambiazo, V. Transcriptomic Changes of Piscirickettsia salmonis During Intracellular Growth in a Salmon Macrophage-Like Cell Line. Front. Cell Infect. Microbiol. 2019, 9, 426. [CrossRef]

60. Abu Khweek, A.; Fernández Dávila, N.; Caution, K.; Akhter, A.; Abdulrahman, B.; Tazi, M.; Hassan, H.; Novotny, L.; Bakaletz, L.; Amer, A. Biofilm-derived Legionella pneumophila evades the innate immune response in macrophages. Front. Cell Infect. Microbiol. 2013, 3, 18. [CrossRef]

61. McCarthy, U.M.; Bron, J.E.; Brown, L.; Pourahmad, F.; Bricknell, I.R.; Thompson, K.D.; Adams, A.; Ellis, A.E. Survival and replication of Piscirickettsia salmonis in rainbow trout head kidney macrophages. Fish Shellfish Immunol. 2008, 25, 477-484. [CrossRef]

62. Perez-Stuardo, D.; Morales-Reyes, J.; Tapia, S.; Ahumada, D.E.; Espinoza, A.; Soto-Herrera, V.; Brianson, B.; Ibaceta, V.; Sandino, A.M.; Spencer, E.; et al. Non-lysosomal Activation in Macrophages of Atlantic Salmon (Salmo salar) After Infection With Piscirickettsia salmonis. Front. Immunol. 2019, 10, 434. [CrossRef] [PubMed]

63. Baldassarri, L.; Bertuccini, L.; Creti, R.; Filippini, P.; Ammendolia, M.G.; Koch, S.; Huebner, J.; Orefici, G. Glycosaminoglycans mediate invasion and survival of Enterococcus faecalis into macrophages. J. Infect. Dis. 2005, 191, 1253-1262. [CrossRef]

64. Daw, K.; Baghdayan, A.S.; Awasthi, S.; Shankar, N. Biofilm and planktonic Enterococcus faecalis elicit different responses from host phagocytes in vitro. FEMS Immunol. Med. Microbiol. 2012, 65, 270-282. [CrossRef] [PubMed]

65. Rozas-Serri, M.; Pena, A.; Maldonado, L. Transcriptomic profiles of post-smolt Atlantic salmon challenged with Piscirickettsia salmonis reveal a strategy to evade the adaptive immune response and modify cell-autonomous immunity. Dev. Comp. Immunol. 2018, 81, 348-362. [CrossRef] [PubMed]

66. Van der Aa, L.M.; Chadzinska, M.; Tijhaar, E.; Boudinot, P.; Verburg-van Kemenade, B.M.L. CXCL8 chemokines in teleost fish: Two lineages with distinct expression profiles during early phases of inflammation. PLoS ONE 2010, 5, e12384. [CrossRef]

67. Zou, J.; Secombes, C.J. The Function of Fish Cytokines. Biology 2016, 5, 23. [CrossRef]

68. Stevens, N.T.; Sadovskaya, I.; Jabbouri, S.; Sattar, T.; O'Gara, J.P.; Humphreys, H.; Greene, C.M. Staphylococcus epidermidis polysaccharide intercellular adhesin induces IL-8 expression in human astrocytes via a mechanism involving TLR2. Cell. Microbiol. 2009, 11, 421-432. [CrossRef]

69. Watters, C.; Fleming, D.; Bishop, D.; Rumbaugh, K.P. Host Responses to Biofilm. Prog. Mol. Biol. Transl. Sci. 2016, 142, 193-239.

70. Mittal, R.; Sharma, S.; Chhibber, S.; Harjai, K. Effect of macrophage secretory products on elaboration of virulence factors by planktonic and biofilm cells of Pseudomonas aeruginosa. Comp. Immunol. Microbiol. Infect. Dis. 2006, 29, 12-26. [CrossRef]

71. Arima, S.; Ochi, H.; Mitsuhashi, M.; Kibe, R.; Takahashi, K.; Kataoka, Y. Staphylococcus pseudintermedius biofilms secrete factors that induce inflammatory reactions in vitro. Lett. Appl. Microbiol. 2018, 67, 214-219. [CrossRef]

72. Rathore, S.S.; Cheepurupalli, L.; Gangwar, J.; Raman, T.; Ramakrishnan, J. Biofilm of Klebsiella pneumoniae minimize phagocytosis and cytokine expression by macrophage cell line. bioRxiv 2019, 623546. [CrossRef]

73. Guilhen, C.; Miquel, S.; Charbonnel, N.; Joseph, L.; Carrier, G.; Forestier, C.; Balestrino, D. Colonization and immune modulation properties of Klebsiella pneumoniae biofilm-dispersed cells. NPJ Biofilms Microbiomes 2019, 5, 25. [CrossRef] [PubMed]

74. Alboslemy, T.; Yu, B.; Rogers, T.; Kim, M.H. Staphylococcus aureus Biofilm-Conditioned Medium Impairs Macrophage-Mediated Antibiofilm Immune Response by Upregulating KLF2 Expression. Infect. Immun. 2019, 87. [CrossRef] [PubMed]

75. Schommer, N.N.; Christner, M.; Hentschke, M.; Ruckdeschel, K.; Aepfelbacher, M.; Rohde, H. Staphylococcus epidermidis uses distinct mechanisms of biofilm formation to interfere with phagocytosis and activation of mouse macrophage-like cells 774A.1. Infect. Immun. 2011, 79, 2267-2276. [CrossRef] [PubMed]

76. Rise, M.L.; Jones, S.R.M.; Brown, G.D.; von Schalburg, K.R.; Davidson, W.S.; Koop, B.F. Microarray analyses identify molecular biomarkers of Atlantic salmon macrophage and hematopoietic kidney response to Piscirickettsia salmonis infection. Physiol. Genom. 2004, 20, 21-35. [CrossRef]

77. Rozas-Serri, M.; Peña, A.; Arriagada, G.; Enríquez, R.; Maldonado, L. Comparison of gene expression in post-smolt Atlantic salmon challenged by LF-89-like and EM-90-like Piscirickettsia salmonis isolates reveals differences in the immune response associated with pathogenicity. J. Fish Dis. 2018, 41, 539-552. [CrossRef] 
78. Bottero, V.; Imbert, V.; Frelin, C.; Formento, J.L.; Peyron, J.F. Monitoring NF-kappa B transactivation potential via real-time PCR quantification of I kappa B-alpha gene expression. Mol. Diagn. 2003, 7, 187-194.

79. Ferreiro, D.U.; Komives, E.A. Molecular mechanisms of system control of NF-kappaB signaling by IkappaBalpha. Biochemistry 2010, 49, 1560-1567. [CrossRef]

80. Parrino, B.; Carbone, D.; Cirrincione, G.; Diana, P.; Cascioferro, S. Inhibitors of antibiotic resistance mechanisms: Clinical applications and future perspectives. Future Med. Chem. 2020, 12, 357-359. [CrossRef]

81. Azad, I.S.; Shankar, K.M.; Mohan, C.V.; Kalita, B. Uptake and processing of biofilm and free-cell vaccines of Aeromonas hydrophila in Indian major carps and common carp following oral vaccination-antigen localization by a monoclonal antibody. Dis. Aquat. Organ. 2000, 43, 103-108. [CrossRef]

82. Kahieshesfandiari, M.; Sabri, M.Y.; Ina-salwany, M.Y.; Hassan, M.D.; Noraini, O.; Ajadi, A.A.; Isiaku, A.I. Streptococcosis in Oreochromis sp.: Is feed-based biofilm vaccine of Streptococcus agalactiae effective? Aquacult. Int. 2019, 27, 817-832. [CrossRef]

Publisher's Note: MDPI stays neutral with regard to jurisdictional claims in published maps and institutional affiliations.

(C) 2020 by the authors. Licensee MDPI, Basel, Switzerland. This article is an open access article distributed under the terms and conditions of the Creative Commons Attribution (CC BY) license (http://creativecommons.org/licenses/by/4.0/). 